\title{
Agrarian and economic aspect of food supply and its safety at the regional level
}

\author{
N. V. Rodnina, M. E. Tarasov, M. M. Teryutina*, and A. N. Kundyaitseva
}

Sectoral Economics and Management department, Economic faculty, Yakut State Agricultural Academy, 677007 Yakutsk, Russia

\begin{abstract}
The article deals with the need of increasing the competitiveness of rural areas in the food market and the share of local products in food supply of the population of the Saha Republic with local products. A system is substantiated that covers the necessity of state protectionist economic and social policy strengthening on the development of the northern regions, the creation of conditions for the agricultural sector of the economy effective functioning and the need to maintain a state support. It is emphasized that a stable economy always plays a crucial role in ensuring food security.
\end{abstract}

\section{Introduction}

Food supply and its safety are very important nowadays. It is not accidental that in recent years the problems of food security have been actively discussed. The National Consumer Protection Fund defined "food security" as "the ability of the state provided with food resources, potential and guarantees regardless of external and internal conditions or threats to meet the needs of the country's population as a whole and each citizen individually with food, drinking water and other food products in volumes, quality and assortment necessary and sufficient for the physical and social development of personality, ensuring health and expanding reproduction of population "[1].

These issues are always based on the possibilities of modernization and sustainable development of the economy of the Republic of Sakha (Yakutia). They directly depend on the human capital quality and require increasing the competitiveness of rural areas in the food market, which are characterized by the goal of agricultural specialization [2]. In addition, due to the low bioclimatic potential of agriculture, the regions assigned to the Far North and equivalent sites need a special approach and support from the federal government.

The Republic of Sakha (Yakutia) is located in the continental part of the Eurasian continent and has the area of 3.102 million $\mathrm{km} 2$. Almost $80 \%$ of the territory lies north of $60^{\circ} \mathrm{N}$, and $40 \%$ lies beyond the Arctic Circle [3]. Agriculture is mainly developed in the medium taiga subzone, the border of which runs along $64-65^{\circ} \mathrm{N}$ and the subzone itself occupies $38 \%$ of the territory of the republic, that is 1103 thousand $\mathrm{km} 2$. The first attempts to take into account the natural conditions in agriculture were made in the 1980-90s [4]. And in such open spaces and harsh extreme conditions that have a negative impact on the final results of economic activity, the republican agro-industrial complex workers are engaged in solving the problems of providing the population with food and processing local food products.

Despite all the difficulties, the main goal of agricultural sector of the economy remains a stable increase in the level of food supply for population. Thus, the agribusiness system of the republic is developing and functioning in extreme conditions, which is a negative factor. All this leads to an objective multiple regional rises in price through the entire production chain of processing the local food products. In addition, in recent years, we have repeatedly pointed out the absence or insufficient nature of scientifically substantiated protectionism in the state's economic and social policies for the development of the northern regions on the basis of food security as a guaranteed provision of essential food products to maintain a normal human life, families and societies with the exception of possible risks in the life support of the population [5].

\section{Methods and materials}

In the analysis of food security (food safety), the most widely used method of comparison is applied. The authors conducted all studies based on the data of the territorial body of the Federal State Statistics Service in Republic of Sakha (Yakutia) as well as comparative analysis and research in the works of Russian scientists on the problems of objective laws in the field of food supply, regulatory and instructive acts, measures of state regulation and their impact on the agrarian food market.

The product security analysis of the population in the Republic of Sakha (Yakutia) in accordance with the physiological norms of consumption as a whole shows that the population is provided with the main types of

\footnotetext{
*Corresponding author: m_teryutina@mail.ru
} 
food. At the same time, the level of regulatory support is mainly achieved by the import of food from other regions of Russia as well as raw materials for production of certain types of food products, including from abroad.
Certain types of agricultural products produced in the Republic cover the needs of the local population for meat by an average of $31.2 \%$, for milk by $64.0 \%$ and for eggs by $48.3 \%$ of the established consumption standard.

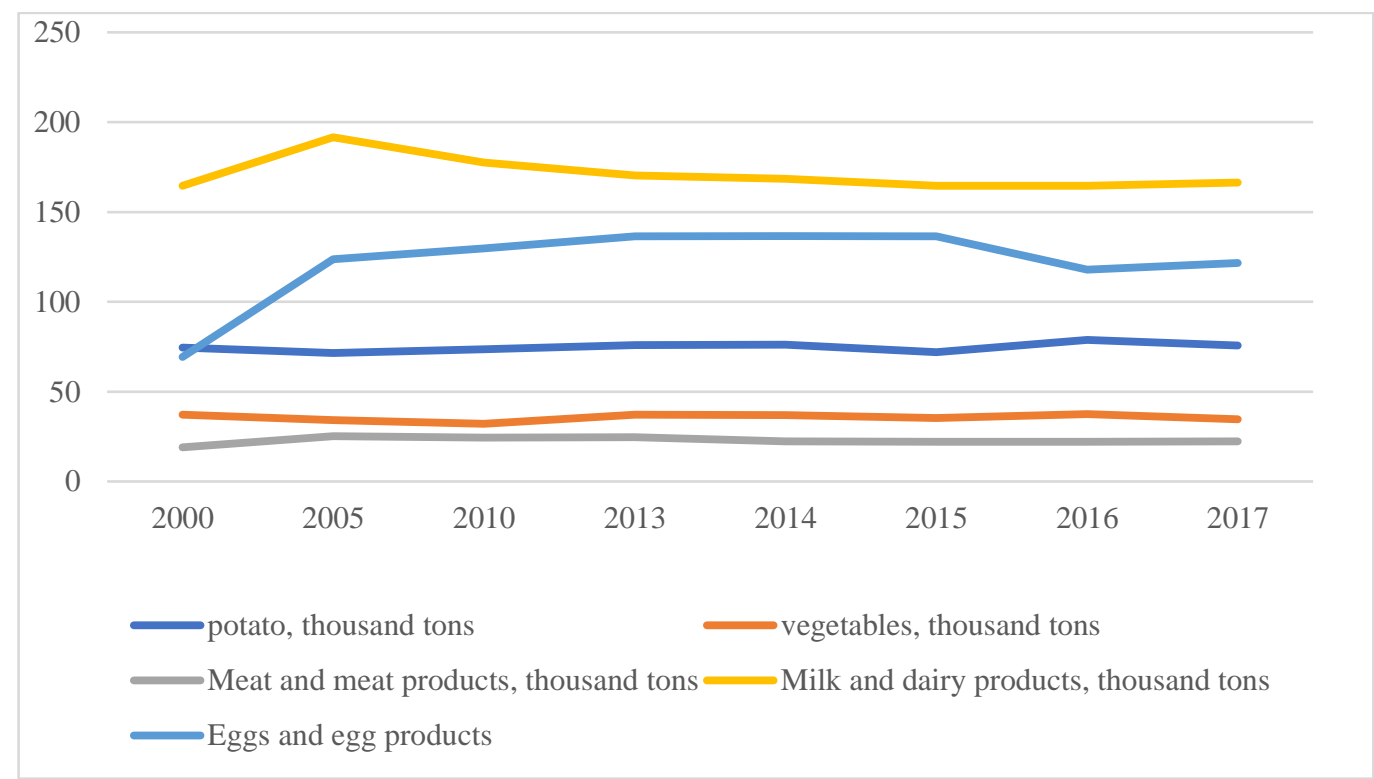

Fig. 1. Production of certain types of agricultural products in the Republic of Sakha (Yakutia)

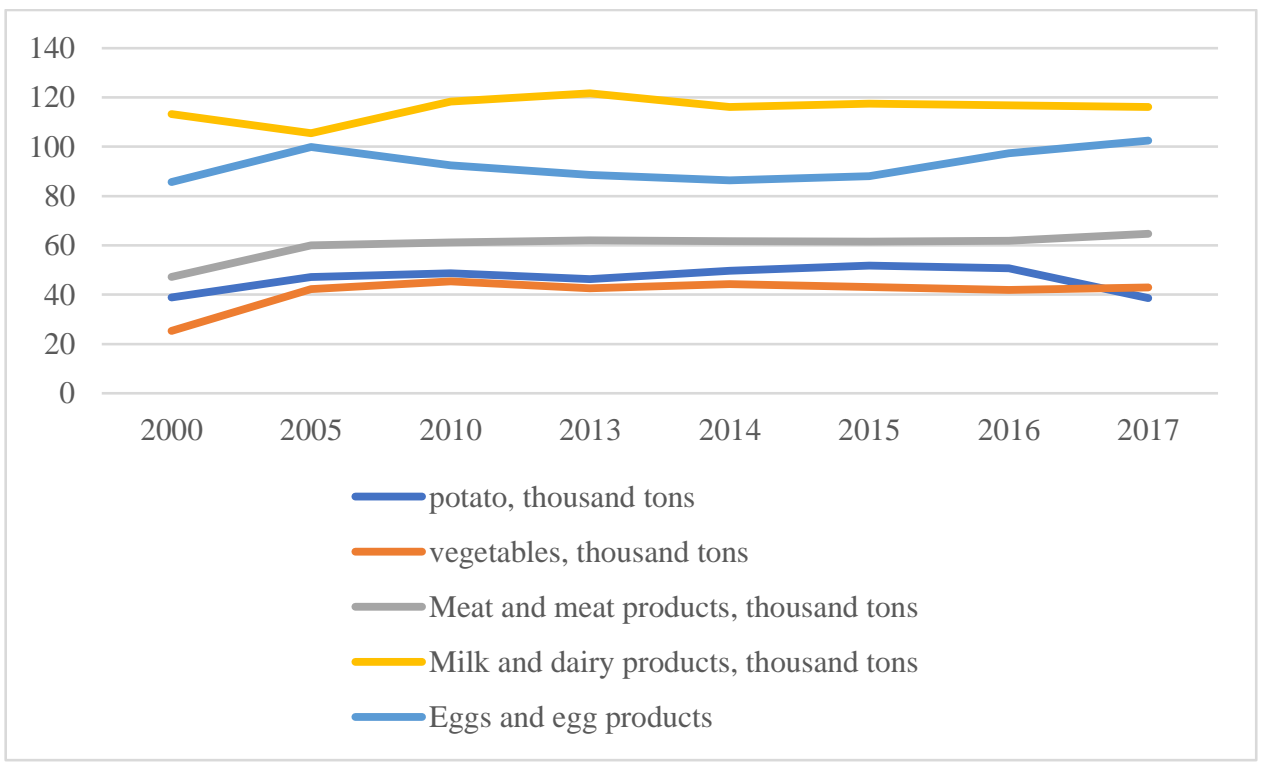

Fig. 2. Import of agricultural products from the borders of the Republic of Sakha (Yakutia)

A feature of the agribusiness of the republic is a high proportion of personal subsidiary plots of the population and farms (tab. 1). Due to a lack of funds, these categories of farms use outdated soil cultivation technologies, they use no or insufficient amount of organic and mineral fertilizers; manual labor prevails in animal husbandry.

This results in low and annually decreasing production indicators, including per capita values (Fig. 3).

25-30\% more petroleum products are consumed, giving 30-35\% increase in the cost of maintenance of equipment in the Republic of Sakha (Yakutia) due to the difficult climatic conditions. Moreover, the radius of cargo transportation increases 2 - 3 times because of the vastness of the territory in comparison with the average for the Russian Federation. Consequently, the level of competitiveness of goods produced in the Republic is not much lower than in other subjects of Russia.

The existence of the food supplying system of the Republic is an objective necessity, as the level and quality of life of the population depends on the effectiveness of its functioning. Therefore, the state should contribute to making conditions for the effective functioning of the agricultural sector of the economy. 
Table 1. The structure of gross agricultural output by categories (in actual prices)

\begin{tabular}{|l|c|c|c|c|c|c|c|}
\hline & $\mathbf{2 0 1 0}$ & $\mathbf{2 0 1 1}$ & $\mathbf{2 0 1 2}$ & $\mathbf{2 0 1 3}$ & $\mathbf{2 0 1 4}$ & $\mathbf{2 0 1 5}$ & $\mathbf{2 0 1 6}$ \\
\hline Farms of all categories including: & 100 & 100 & 100 & 100 & 100 & 100 & 100 \\
\hline $\begin{array}{l}\text { Agricultural enterprises and subsidiary } \\
\text { farms of non-agricultural organizations }\end{array}$ & 27.0 & 25.8 & 24.5 & 25.5 & 25.5 & 26.7 & 27.3 \\
\hline $\begin{array}{l}\text { Peasant (farm) enterprises and } \\
\text { individual entrepreneurs }\end{array}$ & 25.5 & 26.5 & 25.4 & 25.4 & 25.4 & 25.7 & 25.8 \\
\hline Households & 47.5 & 47.7 & 50.1 & 50.1 & 49.1 & 47.7 & 46.9 \\
\hline
\end{tabular}

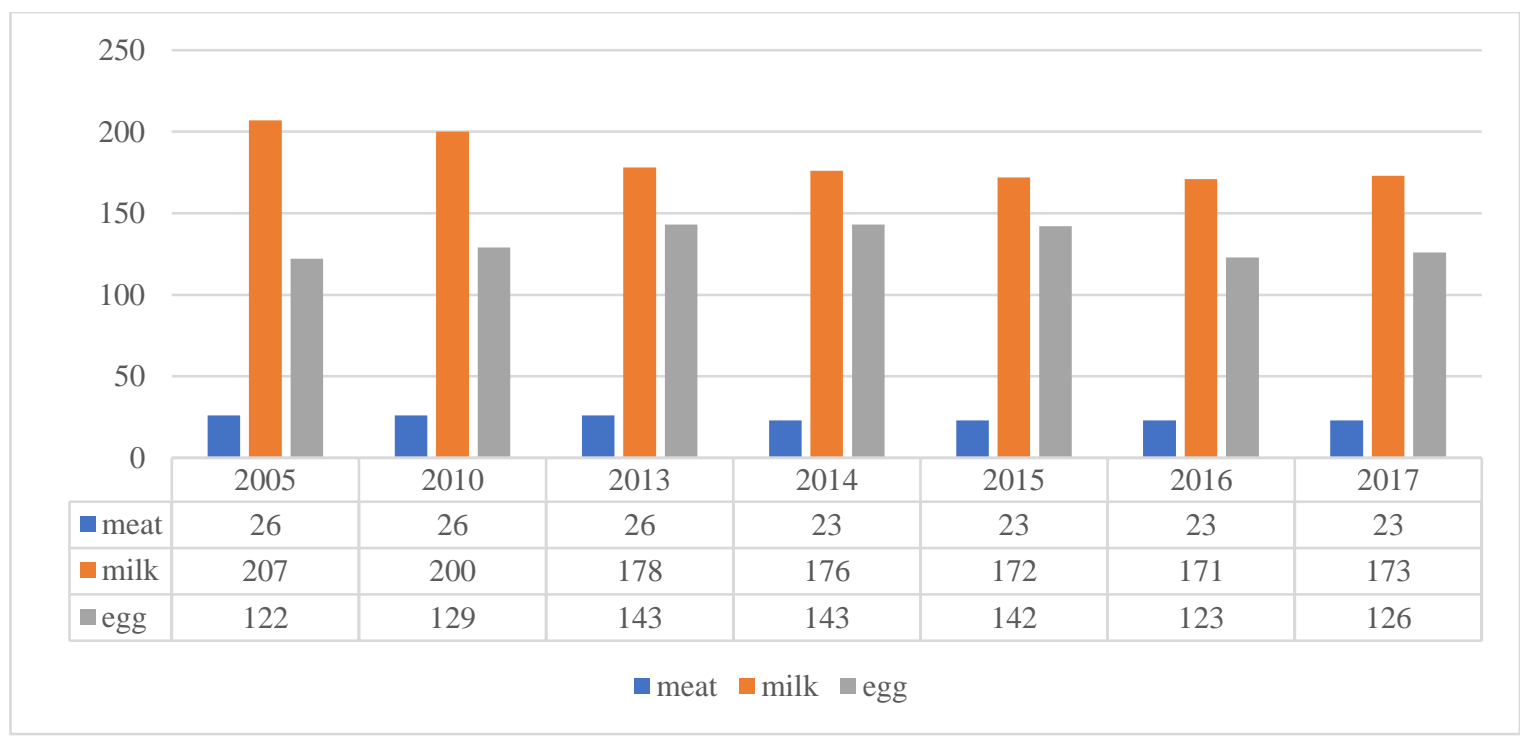

Fig. 3. Indicators of certain types of production of agricultural products per capita in the Republic of Sakha (Yakutia)

Meanwhile, there is an ongoing greater functional decentralization of the executive power in the market; it provides the population with food, both in Russia and in the Republic of Sakha (Yakutia).

The population food supply at the expense of regional (or as recently, it is accepted to say "local") production is a condition for not only secure existence, but also possibility of influence on development of financial and economic indicators of the Republic.

The amount of food imported to the region increases, domestic production decreases. It means that there is an outflow of financial resources from local enterprises and there is the threat to public health because of poor quality and harmful elements of food.

The food security achievement at the household level implies ensuring the proper amount of food in a particular territory, a relatively stable supply of food and guaranteeing each person who needs food in that territory the opportunity to get it in order to lead a healthy and productive life [4].

Table 2. Key performance indicators of agricultural organization

\begin{tabular}{|l|c|c|c|c|c|c|c|}
\hline \multicolumn{1}{|c|}{ number of agricultural } & $\mathbf{1 9 9 0}$ & $\mathbf{2 0 0 0}$ & $\mathbf{2 0 1 0}$ & $\mathbf{2 0 1 2}$ & $\mathbf{2 0 1 5}$ & $\mathbf{2 0 1 6}$ & $\mathbf{2 0 1 7}$ \\
\hline $\begin{array}{l}\text { The } \\
\text { organizations at the end of the year, } \\
\text { units }\end{array}$ & 166 & 266 & 297 & 324 & 81 & 64 & 127 \\
\hline Strength: & & & & & & & \\
\hline $\begin{array}{l}\text { - agricultural workers, * thousand } \\
\text { people }\end{array}$ & 64.3 & 19.3 & 3.8 & 3.3 & 2.7 & 2.4 & 2.4 \\
\hline - employed in agriculture ** & $* * *$ & 50.1 & 42.1 & 41.1 & 32.9 & 34.0 & 35.1 \\
\hline $\begin{array}{l}\text { Agricultural production at actual } \\
\text { prices, mln. Rub. }\end{array}$ & 280.0 & 1074.8 & 4836.2 & 4818.4 & 6321.3 & 6820.2 & 6556.5 \\
\hline
\end{tabular}

* Since 2013, data are presented for agricultural enterprises excluding small businesses.

** agriculture, hunting, forestry.

*** no data. 
The situation is aggravated by the outflow of labor not only from the agricultural sector, but also from the countryside. In rural areas, a decrease in the number of agricultural enterprises and organizations is observed (Table 2). The solution of the tasks to increase the share of agriculture in the gross regional product and increase the food self-sufficiency index of the republic should be achieved by improving the interconnections and relations of all levels of government, including local.

At the same time, the weak impact of the institution of local self-government on the development of production facilities and rural areas indicates that at this level of governance, until the full conditions for the development of agriculture are created, despite the consolidation of state self-government powers in terms of creating conditions for the development of local agriculture. Lack of financial resources, lack of qualified personnel do not provide the agrarian sector with innovative development. Territory management, both in Russia and in the republic, does not have an integrated approach.

\section{Results and discussion}

The authors of the article believe that the main indicator reflecting the level of food safety is the level of food selfsufficiency, be it that of a state as a whole or an individual region of the Russian Federation.

The food supply of the population living in the North was the prerogative during the Soviet period; it was a subject of the centralized state administration. Nevertheless, with the beginning of radical economic transformations in the 1990s, this burden was shifted to the regional level.

In this connection, food supply, characterized by sources of resources formation of the main types of food products and their use, or in other words, the food balance (the balance of commodity food resources) should be the main direction of the state agricultural policy of the Republic of Sakha (Yakutia) [5].

What is the feature of our Northern conditions? In the current legislation, there is no single concept of "state regulation", which is quite understandable, since "there is no system-forming act on the regulation of economic activity". In some cases, the legal definitions of the state regulation are fixed in the relation to individual areas of the economy. However, today the state regulation of the agricultural complex is the most important part of the economy market mechanism in all developed countries [6]. The need for such regulation is connected with the inherent features of the agricultural complex, which is prevent it from competing against other sectors on par. Agriculture depends on natural factors and has a pronounced seasonal nature and is as a rule more backward in technology. The material and financial resources invested in it are less efficient. Besides, it slowly adapts to changes in the ecological and technological conditions.

However, the state support system of agriculture and its state regulation, its features in the development of production support must be saved by virtue of the Federal law of December $26^{\text {th }}$, 2006 № 264 “On Development of
Agriculture". The main provisions of priority development in the village social sphere and the material and technical base of the agricultural complex are determined in the structure of the Russian Federation national economy.

Besides, the state strives to provide a fair competition on the commodity markets, to defend some categories of consumers. The interests of society as a whole, which in the outcome allows forming the public food resources, are to support the income of commodity producers and regulate the market situation for the main types of agricultural products (grain, oilseeds, and wool, processing products). It should be noted that in July 2014 the Government of the Russian Federation approved the Concept of Domestic Food Aid Development in the Russian Federation, which was based on the provisions of the Food Security Doctrine of the Russian Federation, approved by President Decree of the Russian Federation in 2010. Like any strategically important document, the Concept has a goal and defines a number of tasks.

There is still an aspiration to implement it in relation to a particular region, and even more so if this region is in severe climatic conditions with low transport accessibility, seasonality of delivery of goods and a number of other negative factors.

Achieving this goal namely the share of Russian agricultural products and food in providing the system of domestic food assistance to Russia with at least 80 percent is an important economic development indicator and a key condition for supporting the health of the country's population.

It can be seen, that now the presence of the main resources of agricultural products and raw materials, the saturation of the Russian Federation and the Saha Republic food market in the main physical access to food are provided at least at a minimum level consumption [7].

In this regard, we provide data showing acceptable indicators of food security, which were proposed from the world practice [10].

It is important to emphasize that the highest degree of safety is achieved by providing the entire set of indicators to be within the permissible limits of their threshold values, and the threshold values of one indicator are not achieved to the detriment of others. For example, a decrease in the inflation rate to a limit level should not lead to an increase in the unemployment rate above the permissible limit, or a decrease in the budget deficit to a threshold value - to a complete freezing of capital investments and a drop in production [11].

Today, whatever you may say, in the agricultural sector, for a number of well-known reasons, both internal and external, it has become much more difficult and costly to solve the numerous problems of food supply. Nevertheless, food security in the country and in the republic is ensured, and to a certain extent, this has been achieved due to the growth of production of agricultural products and food industry in Russia in the last decade. It increased the country's self-supply with the main types of agricultural products and food, including regions located in the North of the country.

It increases the level of the main country self-reliance of the agricultural products and food including regions 
located in the North of the country. At the same time, we must note that the country food market, the situations with the short-term deficiency of different types products in some Northern regions systematically arise and consumers are not protected from the sharp fluctuations of food prices. This is due to a number of factors including a different level of the rural industry development, particularly in the Russian northern regions, poor infrastructure in some territories, remoteness and the seasonal nature of food delivery and a number of others.

Table 3. Comparison of food safety thresholds and real development parameters of the Russian economy (Stepanova, 1999)

\begin{tabular}{|c|c|c|c|}
\hline \multirow{2}{*}{ Food security indicator } & \multicolumn{2}{|c|}{ Extreme critical values, $\%$} & \multirow{2}{*}{$\begin{array}{l}\text { Probable socio-political and } \\
\text { economic violations of the } \\
\text { criteria for safety measures }\end{array}$} \\
\hline & In global practice & In Russia & \\
\hline $\begin{array}{l}\text { The share of food imports in } \\
\text { domestic consumption }\end{array}$ & 25 & $\begin{array}{c}30 \text { or more } \\
\text { according to } \\
\text { various sources }\end{array}$ & Loss of food independence \\
\hline Quality Food Products & 100 & $\begin{array}{l}\text { For certain types of } \\
\text { imported products } \\
50 \text { and less }\end{array}$ & $\begin{array}{l}\text { Immediate threat to the } \\
\text { health of the nation }\end{array}$ \\
\hline $\begin{array}{c}\text { Share of population with } \\
\text { incomes below the subsistence } \\
\text { level }\end{array}$ & $7-10$ & 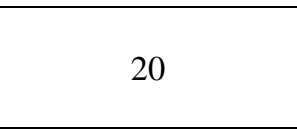 & $\begin{array}{l}\text { The threat of social stability } \\
\text { in society }\end{array}$ \\
\hline $\begin{array}{c}\text { The level of investment in fixed } \\
\text { assets of agriculture }\end{array}$ & $30-50$ & $3-4$ & $\begin{array}{l}\text { The threat of production } \\
\text { degradation, the beginning } \\
\text { of destructive processes }\end{array}$ \\
\hline
\end{tabular}

Table 4. Minimum standards for the consumption of food products (average per person per year), $\mathrm{kg}$

\begin{tabular}{|l|c|c|c|}
\hline \multicolumn{1}{|c|}{ Name } & Working population & Retired & Children \\
\hline $\begin{array}{l}\text { Bread products (bread and } \\
\text { pasta in terms of flour, } \\
\text { cereals, legumes }\end{array}$ & 133.7 & 103.7 & 84.0 \\
\hline Potato, kg & 107.6 & 80.0 & 107.4 \\
\hline Vegetables and melons, kg & 97.0 & 92.0 & 108.7 \\
\hline Fresh fruits & 23.0 & 22.0 & 25.9 \\
\hline $\begin{array}{l}\text { Sugar and confectionery in } \\
\text { sugar equivalent }\end{array}$ & 22.2 & 21.2 & 33.7 \\
\hline Meat products & 37.2 & 31.5 & 14.0 \\
\hline Fish products & 16.0 & 15.0 & 325.2 \\
\hline $\begin{array}{l}\text { Milk and dairy products in } \\
\text { milk equivalent }\end{array}$ & 238.2 & 218.9 & 193.0 \\
\hline Eggs & 200.0 & 180.0 & 10.0 \\
\hline $\begin{array}{l}\text { Vegetable oil, margarine } \\
\text { and other fats }\end{array}$ & 13.8 & 11.0 & - \\
\hline $\begin{array}{l}\text { Other products (salt, tea, } \\
\text { spices) }\end{array}$ & 4.9 & 4.2 & \\
\hline
\end{tabular}

\section{Conclusion}

Thus, the fundamental condition for achieving food security is an income growth and poverty reduction, which determines the affordability of food. In addition, consumer demand and the level of per capita consumption of food products depends on the ratio of the growth rate of the population's cash incomes to the prices of food products.

At the same time, the fundamental condition for attaining the food supply are the income growth and reduced poverty rate, as they define the economic availability of products. In addition, the consumer demand and the level of per capita food consumption depends on the growth rate ratio of population money incomes and food prices.

In this aspect, if we take only the economic sphere, a stable economy always plays a decisive role in ensuring food security because food security is one of the types of economic security. All the key problems of agroindustrial and economic reform converge in this area, as are the real trends of agricultural and food production development, the domestic food market, social status and solvency of consumers in different regions of Russia.

We emphasize once again that considering food supply as a set of economic relations in society arising from the provision of all its members with food products of relevant quality and quantity standards, the state must guarantee the availability, stability and efficient use of food. 
All actions on increasing the food supply level should be based on improving the mechanisms of state regulation, effective models and methods for managing the agricultural sector, the social development of the region with the main vector aimed at improving the living standards of population. All of it is supported on the basis of new technologies, growth of labor productivity, in general, the country's economic management system [12].

Hence, the conclusion is that for a healthy and productive life of a person, their physical and social development, the state must guarantee every person a unobstructed access to food, achieving national food safety.

This can be achieved only by relying on the existing state and regional programs of agriculture and regulation of food markets development based on the Concept of Long-Term Social and Economic Development of the Russian Federation for the Period Until 2020 (approved by Decree of the Russian Federation Government on November 17, 2008, No. 1662) and the Doctrine of Food Security of the Russian Federation (approved by Decree of the President of the Russian Federation dated January 30, 2010 No. 120). Strategic purpose of these documents is to provide the country's population with safe produce, fish and other products from aquatic bioresources and food [13].

It seems paradoxical to us to assert that in modern market conditions the regulatory role of the state should increase even more. Because the economic system, focused on the active use of market mechanisms in agriculture is inconceivable without government intervention. It represents the selection and implementation of the most rational organizational and economic forms, methods and means of ensuring the efficiency and sustainability of agricultural production especially in the North.

\section{References}

1. S.V. Kiselev, Development of agrifood markets and the problems of Russia's entry into the WTO, Economics of agricultural and processing enterprises, 7, 18-20 (2011)

2. V.I. Kondratieva, ed., The Arctic: sustainable development prospects: a collection of reports by the participants of the Int. sci. pract. conf. (Yakutsk, November 26-28, 2014) 144 (Yakutsk Center of Strategic Research in the Sakha Republic, Yakutia, 2015)

3. Yakutia. Historical and Cultural Atlas: Nature. Story. Ethnography. Modernity, 16-18 (Government of the Republic of Sakha, Yakutia; Institute for Humanitarian Studies, Academy of Sciences of the Republic of Sakha, Yakutia; Publishing House THEORY, Moscow, 2007)
4. The agricultural system in the Republic of Sakha (Yakutia) for the period 2016-2020, Toolkit, 7 (Yakutsk Research Institute of Agricultural Sciences, Yakutsk, 2017)

5. A.A. Pakhomov, E.Ya. Fedorova, V.R. Darbasov, Food Security of Yakutia: Theory and Practice, 8 (Novosibirsk, Nauka, 2016)

6. Food security of the country: agrarian-economic aspect, retrieved from: http://old.nasledie.ru/politvnt/ 19_31/article.php?atr=10

7. N.V. Rodnina, Economic, social, organizational problems of food supply in the Republic of Sakha Yakutia: theory and management methods, 5-6 (Agency Sakha, Yakutsk, 2010)

8. E.G. Egorov, V.R. Darbasov, Agrarian economy of the North, 132-137 (Dani Almas Company, Yakutsk, 2008)

9. N.V. Beketov, M.E. Tarasov, Problems of food safety in Russia. National interests, priorities and safety. Science, practice, theory magazine, 4, 28 (February 2009)

10. N.G. Stepanova, Food Security in the Process of Social Production, candidate dissertation (Moscow, 1999)

11. V.R. Darbasov, A.G. Nikiforov, Food supply of Yakutia: theory, experience, problems, 8-10 (Nauka, 2007)

12. A.A. Popov, A.N. Myreev, S.V. Fedorova, The quality of life in the context of economic transformation: theory, problems, practice (on the example of the Far North regions and the Arctic zone), monograph, 391 (NEFU Publishing House, Yakutsk, 2015)

13. M.E. Tarasov, A.N. Bysyina, Regional food security: state, problems and trends, Sci.-pract. and analytical j. Regional Economics: Theory and Practice, 25(304), 12 (July 2013)

14. I.I. Sleptsov, M.E. Tarasov, M.M. Teryutina, On the main features of state regulation of the agrarian economy and agricultural production, in Innovative approaches to problems and prospects for the development of the agro-industrial complex in the Republic of Sakha (Yakutia): materials of reports of the Int. Sci. and Pract. Conf. dedicated to the 100th anniversary of the birth of Professor Mikhail Grigorievich Safronov and the 60th anniversary of the Yakutsk Research Institute of Agriculture named after M.G. Safronov (Yakutsk, December 9, 2016), 335 (Federal Agency of Scientific Organizations of Russia, Federal State Budget Scientific Institution, Yakutsk Scientific and Research Institute of Agriculture named after M.G. Safronov; PublishPrint, Voronezh, 2017) 